\title{
FINANCIAL MANAGEMENT PRACTICES FOR FARM PROFITABILITY
}

https://doi.org/10.47743/jopafl-2021-21-04

\author{
Andrei-Cristian MATEI \\ Alexandru Ioan Cuza University of Iași, Faculty of Economics and Business \\ Administration \\ Iași, Romania \\ mateiandrei135@gmail.com
}

\section{Mihaela ONOFREI}

Alexandru Ioan Cuza University of Iași, Faculty of Economics and Business

Administration

Iași, Romania

onofei@uaic.ro

\begin{abstract}
This research is based on two studies that could help farm managers make financial decisions about equipping a dairy farm with an automatic milking system or conventional milking system or for choosing the most profitable hybrid maize used in agriculture for the production of maize grains. The data were collected following the accounting of agricultural companies. In the case of the analysis of the most efficient milking system, a t test was used to compare the farms according to the technology used and the statistical calculations were performed with IBM SPSS V.22 software. The second study was based on four maize hybrids, marketed by different organic production companies. Two variables were studied: the purchase price of the seed/ha and the productivity/ha for each of the 4 maize hybrids for which the relationship between the purchase price of the seed / ha and the productivity/ha of each seed hybrid was analyzed statistically corn under study. It was observed that the economic efficiency of farms is similar regardless of the milking system, for large farms the conventional milking system could be more profitable. In the case of maize hybrids, a direct connection is observed between the two variables because the higher the purchase price of the seed/ha, the higher the productivity per ha.
\end{abstract}

Keywords: Financial decision, Agricultural companies, milk production, corn production.

This Article was presented as a paper at the $13^{\text {th }}$ edition of the Annual International Conference Globalization and Higher Education in Economics and Business Administration (GEBA 2021), which was held at the Alexandru Ioan Cuza University, Faculty of Economics and Business Administration in Iasi, Romania from the $21^{\text {st }}$ to $23^{\text {rd }}$ of October 2021.

\section{Introduction}

The economic environment is characterized by a continuous process of search and analysis of tools and mechanisms that can lead to better financial management and thus to an increase in overall performance (Onofrei M., 2007). The economic importance of agriculture is found in the fact that part of the labor force in rural and urban areas is employed in this field, both for the production of agricultural products and machinery and 
equipment used in agriculture (Scown and Nicholas, 2020). Agriculture is an instrument of economic development in rural areas. The purpose of agricultural holdings in the livestock and plant sector, in the current period, is to increase the quantity and quality of production obtained in order to meet the requirements imposed by the U.E. Financial decisions, in general, present elements of uncertainty due to the impossibility of predicting the future with maximum accuracy (Maina F. el al., 2018). Thus, certain unforeseen changes such as the price of a product or the fluctuation of the exchange rate or changes in interest rates lead to the destabilization of the activity. The number of dairy farms exploited for milk production, using the automatic milking system (AMS), is constantly growing, especially in Eastern Europe (Bijl R. et al., 2007). In 1987, the Dutch company Lely invented the milking robot, starting marketing in countries with advanced animal husbandry. In Romania, approximately $6 \%$ of farms use AMS, this percentage is constantly increasing (Matei A.C. et al., 2020). It is recognized that in agriculture, animal husbandry is a basic sector, especially in economic terms in countries considered developed, being the main source of high biological value proteins indispensable for human nutrition. One of the main reasons for investing in an automatic milking system is the desire to have a more flexible work schedule, but also more free time (Tse C. et al., 2017). Indeed, some previous research has reported labor savings after the adoption of the AMS, but at the same time it has been hypothesized that capital expenditures would increase due to high maintenance costs but also a much higher investment (Bravo-Ureta B.E. et al., 2007). The change in the milking system coincides with a change in daily work activities, which requires more attention to check the dairy cows. Maina et al. (2018) found that the adoption of new technologies in the dairy sector requires considerable investment with high capital expenditures. Efficiency is a major problem in the economy of agricultural production and is measured by comparing the value obtained with that expected (Scown and Nicholas, 2020). Economic efficiency in the case of farms is a product of technical efficiency together with allocation efficiency. In agriculture, the choice of hybrids is one of the most important factors influencing productivity/ha, often being able to even differentiate between profit and loss (Coleman and Hemsworth, 2014.) When choosing a maize hybrid, some details such as the temperature in the growing area, the level of annual rainfall, the incidence of diseases, soil nutrients, etc. must be taken into account, but many farm managers are easily influenced by the idea that the more expensive the seed for sowing, the higher the productivity, but this principle is not a healthy one for the companys budget (Scown and Nicholas, 2020).

\section{Materials and methods}

This research is based on two studies that could later help farmers make financial decisions about investments, such as equipping a dairy farm with an automatic milking system or a conventional milking system or choosing the most profitable corn hybrid. used in agriculture for the production of corn grains. The data collected for the first study come from the accounting records of dairy cows, registered in 2018. In this research, we studied 10 farms that use the automatic milking system and 20 farms that use conventional milking systems. The database included information on income (eg income from milk production and other agricultural activities), fixed costs (eg maintenance costs of buildings and machinery), variable costs (eg food costs, breeding costs, energy, water). All revenues and expenditures are expressed in one tonne of milk (using the total quantity of milk quota), 
and subsequently these results were analyzed with a t test to compare farms with CMS with those with AMS. Statistical calculations were performed with IBM SPSS V.22 software.

The second study was based on four maize hybrids, marketed by different organic production companies. The data were collected following the accounting records of agricultural companies that produced grain maize, in non-irrigated system, in 2020. The database included information on the purchase price of the seed/ha, the selling price of production, productivity/ha , density of plants at sowing, etc. The 4 corn hybrids were sown on nearby soils benefiting from the same maintenance conditions as: precipitation $(\mathrm{l} / \mathrm{m} 2)$ : March: 60, April: 62, May: 74, June: 102, July: 14, August: 30; density: 70,000 plants/ha. Sale price of corn grains $1080 \mathrm{RON} /$ to. The expenses for the exploitation of a ha of land for corn production were fixed, for all the 4 corn hybrids studied, ie $1480 \mathrm{RON} / \mathrm{ha}$, to which are added the expenses with the acquisition of the seed which varied between 512-590 $\mathrm{RON} / \mathrm{ha}$. The average productivity was calculated at the standard moisture content of $14 \%$ maize grains. Two variables were studied: the purchase price of the seed/ha and the productivity/ha for each of the 4 maize hybrids. The relationship between the purchase price of the seed/ha and the productivity/ha of each maize hybrid studied was statistically analyzed.

\section{Results and discussions}

The annual economic reports are generally of interest to farmers who pay particular attention to the finances that represent the performance of that farm (Scown and Nicholas, 2020). The farms in this sample can thus be characterized as farms that want to obtain and keep track of financial performance, their purpose being to help make the best management decisions.

Table 1. Description of the input and output variables used to analyze the efficiency and average values (with the std deviation) for farms with automatic milking system (AMS) and those with conventional milking system (CMS)

\begin{tabular}{|c|c|c|c|c|c|c|}
\hline & & \multicolumn{2}{|c|}{ AMS $(n=10)$} & \multicolumn{2}{|c|}{ CMS $(n=20)$} & \multirow[b]{2}{*}{$\begin{array}{c}\text { p- } \\
\text { value }\end{array}$} \\
\hline Variable & $\begin{array}{l}\text { Data from farm } \\
\text { accounting }\end{array}$ & Average & $\begin{array}{l}\text { Standard } \\
\text { deviation }\end{array}$ & Average & $\begin{array}{l}\text { Standard } \\
\text { deviation }\end{array}$ & \\
\hline Animals & $\begin{array}{l}\text { Total number of } \\
\text { cows }\end{array}$ & 176 & 27,9 & 165 & 28,2 & 0,76 \\
\hline \multirow[t]{3}{*}{$\begin{array}{l}\text { Capital expenditure } \\
\text { (RON/ton milk) }\end{array}$} & $\begin{array}{c}\text { Expenses for } \\
\text { buildings }\end{array}$ & 202,2 & 84 & 184 & 79 & 0,91 \\
\hline & $\begin{array}{l}\text { Expenditure on } \\
\text { machinery and } \\
\text { equipment }\end{array}$ & 401,5 & 170 & 304,4 & 150,2 & 0,0028 \\
\hline & $\begin{array}{r}\text { Total capital } \\
\text { expenditures }\end{array}$ & 603,7 & 254 & 488,4 & 229,2 & 0,0030 \\
\hline $\begin{array}{l}\text { Personnel expenses } \\
\text { (RON/ton milk) }\end{array}$ & Total staff costs & 484,1 & 78 & 512,3 & 176,47 & 0,60 \\
\hline \multirow{3}{*}{$\begin{array}{c}\text { Expenditure on } \\
\text { materials (RON/ton } \\
\text { milk) }\end{array}$} & Feed for animals & 50,23 & 15,43 & 51,4 & 12,82 & 0,28 \\
\hline & $\begin{array}{c}\text { Concentrates }+ \\
\text { premixes }\end{array}$ & 329,32 & 26,74 & 328,46 & 28,5 & 0,98 \\
\hline & Fertilizers & 48,65 & 9,32 & 49,88 & 9,72 & 0,18 \\
\hline
\end{tabular}




\begin{tabular}{|c|c|c|c|c|c|c|}
\hline & Pesticid & 12,3 & 2,78 & 12,1 & 3,14 & 0,096 \\
\hline & Reproduction & 43,42 & 12,4 & 42,98 & 11,8 & 0,68 \\
\hline & Medication & 64,2 & 4,5 & 64,4 & 4,2 & 0,16 \\
\hline & Energy and water & 74,67 & 8,3 & 75,8 & 9,1 & 0,001 \\
\hline & $\begin{array}{l}\text { Elimination of } \\
\text { manure }\end{array}$ & 4,8 & 1,25 & 4,84 & 1,4 & 0,46 \\
\hline & $\begin{array}{c}\text { Total expenditure on } \\
\text { materials }\end{array}$ & 627,59 & 80,72 & 629,86 & 80,68 & 0,12 \\
\hline \multirow{4}{*}{$\begin{array}{c}\text { Revenue (RON/ton } \\
\text { milk) }\end{array}$} & Milk income & 1600 & 130 & 1645 & 129 & 0,74 \\
\hline & $\begin{array}{l}\text { Income from the } \\
\text { sale of animals }\end{array}$ & 120 & 24,5 & 116 & 24,4 & 0,61 \\
\hline & $\begin{array}{l}\text { Revenue from other } \\
\text { activities }\end{array}$ & 25,2 & 4,7 & 24 & 4,7 & 0,45 \\
\hline & Total revenue & 1745,2 & 159,2 & 1785 & 158,2 & 0,90 \\
\hline $\begin{array}{c}\text { Net production } \\
\text { (RON/ton of milk) }\end{array}$ & $\begin{array}{l}\text { Total revenue - } \\
\text { Expenditure on } \\
\text { materials }\end{array}$ & 1117,61 & 78,48 & 1155,14 & 77,52 & 0,77 \\
\hline
\end{tabular}

Table no. 1 presents an overview of the entrances and exits for the 30 farms studied in total. Expenditures and revenues were reported per tonne of milk to allow comparison between lactation farms (305 days) and milk weight in fats and proteins. As expected, capital expenditures were significantly higher for AMS farms than for CMS farms. These higher costs are due to the higher costs of maintenance and construction of buildings and facilities, because in the case of AMS farms the rate of equipment replacement is higher. However, no estimates of the economic life of an AMS are available, so it would be beneficial to assess the lifespan of the AMS to allow a reliable comparison with the farms where CMS is used. In terms of staff costs, they are higher on farms with CMS, RON 512.3/t milk, because more employees are needed to milk cows, while on farms with AMS staff costs do not exceed 484, 1 RON/t milk. The costs of materials are approximately the same in both situations, because the animals benefit from the same ration of food, the same drug treatment, etc. No differences were observed between farms with AMS and those with CMS in the productions sold, the net income resulting from the sale of the productions registering close values. The total revenues for farms with AMS and CMS were 1745.2 RON/t milk and 1785 RON/t milk, respectively, and the net yields were $1117.61 \mathrm{RON} / \mathrm{t}$ milk for farms with AMS and 1155.14 RON/t milk for farms with CMS.

Therefore from table no. 1 it can be seen that farms with AMS have higher capital expenditures, but the net production does not differ between farms with AMS and those with CMS. This shows us that the small, insignificant differences in personnel and material costs observed in CMS farms, compensate for the capital expenditures of AMS farms. Bijl R. et al. (2007) found that investing in AMS is profitable. The results of previous studies showed that investments in AMS were not profitable for farms in the Netherlands and the United States. The results of the current study show that net production does not differ depending on the milking system, indicating that the economic efficiency of farms with AMS and CMS is similar. However, farms that use milking robots are expected to be more profitable in the future, with increased labor and energy and water costs. Maina et al. (2018) found that the implementation of new technologies in the dairy sector requires significant investments with high capital expenditures. A major disadvantage of AMS is that it can milk a limited number of cows/day, and on large farms, such as some in the US, AMS is 
not profitable because it requires a large number of milking robots, which leads to a investment, while labor costs are lower in the US than in Europe (Matei A.C. et al., 2020). Regarding the second study, it was found that there is a correlation between the seed purchase price and productivity per hectare.

Table 2. The characteristics of the corn hybrids studied

\begin{tabular}{|c|c|c|c|}
\hline Company/Hybrid & $\begin{array}{c}\text { Seed purchase price } \\
\text { (RON/ha) }\end{array}$ & $\begin{array}{c}\text { Average productivity } \\
\text { at 14\% humidity } \\
\text { (kg/ha) }\end{array}$ & $\begin{array}{c}\text { Revenue from the sale } \\
\text { of production (RON) }\end{array}$ \\
\hline PIONEER/P9537 & 585 & 9320,80 & $10.066,46$ \\
\hline MONSANTO/DKC5141 & 590 & 9815,44 & 9564,10 \\
\hline KWS/KINEMAS & 544 & 8855,65 & 9572,29 \\
\hline SYNGENTA/COBALT & 512 & 8863,24 & 957 \\
\hline
\end{tabular}

Figure 1. The connection between variables

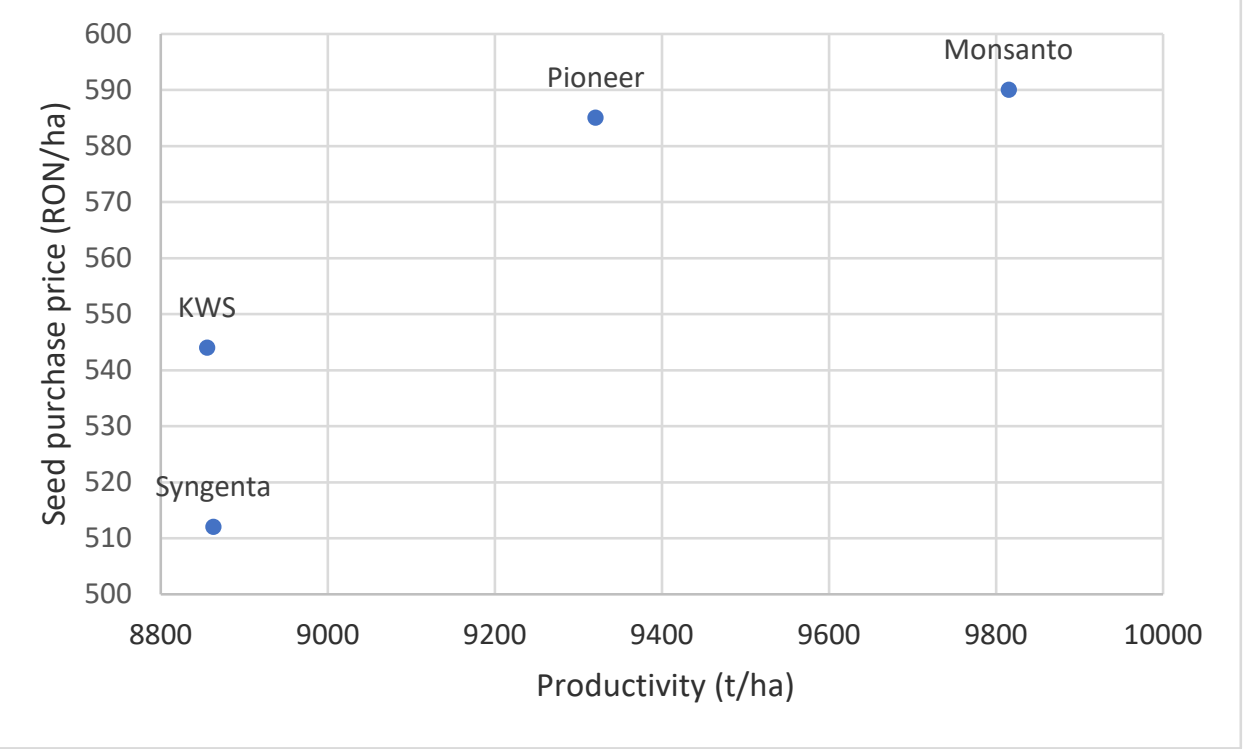

There is a direct bundle between the two variables because the higher the purchase price of the seed/ha, the higher the productivity per ha. However, it is not recommended that a high seed price be expected to have a high yield because traders can change prices depending on demand but not necessarily on quality. In this case, all four hybrids studied were profitable because the expenses varied between 1992 and 2070 RON/ha and the incomes varied between 9564.10 and 10,600.46 RON/ha only from the sale of the production to which can be added the subsidy for diesel and land area subsidy.

\section{Conclusions}

Regarding the study based on dairy farms in Romania that use automatic milking systems and conventional milking systems, to investigate whether the economic efficiency 
differs depending on the milking system, so that in the future farmers can get the best financial decision. Farms with AMS had higher average capital costs (603.7 RON/t milk) compared to CMS farms (488.4 RON/t milk). Total labor costs and net production were not significantly different between AMS farms and CMS farms. Thus, the economic efficiency of farms with AMS and those with CMS was similar.

In the case of the corn hybrids used, a direct connection is observed between the two variables because the higher the purchase price of the seed/ha, the higher the productivity per ha. However, it is not recommended that a high seed price be expected to have a high yield because traders can change prices according to demand but not necessarily according to their productivity or quality.

\section{References}

1. Bijl, R., S. R. Kooistra, and H. Hogeveen. 2007. The profitability of automatic milking on Dutch dairy farms. J. Dairy Sci. 90:239-248. https://doi.org/10.3168/jds.S0022-0302(07)72625-5

2. $\quad$ Bravo-Ureta, B. E., D. Solis, V. H. Moreira Lopez, J. F. Maripani, A. Thiam, and T. Rivas. 2007. Technical efficiency in farming: A meta-regression analysis. J. Prod. Anal. 27:57-72. https://doi.org/10.1007/s11123-006-0025-3

3. Coleman, G. J., and P. Hemsworth. 2014. Training to improve stockperson beliefs and behaviour towards livestock enhances welfare and productivity. Rev. Sci. Tech. 33:131-137. https://doi.org/10 $.20506 /$ rst.33.1.2257.

4. Maina, F., Mburu, J., Gitau, G., VanLeeuwen, J., \& Negusse, Y. 2018. Economic efficiency of milk production among small-scale dairy farmers in Mukurweini, Nyeri County, Kenya. Journal of Development and Agricultural Economics, 10(5), 152-158. https://doi.org/10.5897/JDAE2017.0915

5. Matei A.C., Creangă Șt., Davidescu M.A., Doboș B.I., Porosnicu I., Mădescu B.M.,. 2020. Research on the economic efficiency of farms in the function of the milking system, AgroLife Scientific Journal, București;

6. $\quad$ Onofrei M. 2007. Managent Financiar, Editura C.H. Beck, București;

7. Scown M.W., Nicholas K.A. 2020. European agricultural policy requires a stronger performance framework to achieve the sustainable development goals, Global Sustainability.

8. Tse, C., H. W. Barkema, T. J. DeVries, J. Rushen, and E. A. Pajor. 2017. Effect of transitioning to automatic milking systems on producers' perceptions of farm management and cow health in the Canadian dairy industry. J. Dairy Sci. 100:2404-2414. https://doi.org/10.3168/jds.2016-11521 This article is an open access article distributed under the terms and conditions of the
Creative Commons Attribution - Non Commercial - No Derivatives 4.0 International License. 